\title{
Genomic regions associated with important seed quality traits in food-grade soybeans
}

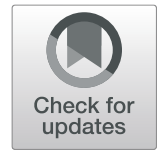

\author{
Rachel M. Whiting, Sepideh Torabi, Lewis Lukens and Milad Eskandari ${ }^{*}$ (D)
}

\begin{abstract}
Background: The production of soy-based food products requires specific physical and chemical characteristics of the soybean seed. Identification of quantitative trait loci (QTL) associated with value-added traits, such as seed weight, seed protein and sucrose concentration, could accelerate the development of competitive high-protein soybean cultivars for the food-grade market through marker-assisted selection (MAS). The objectives of this study were to identify and validate QTL associated with these value-added traits in two high-protein recombinant inbred line (RIL) populations.

Results: The RIL populations were derived from the high-protein cultivar 'AC X790P' (49\% protein, dry weight basis), and two high-yielding commercial cultivars, 'S18-R6' (41\% protein) and 'S23-T5' (42\% protein). Fourteen large-effect QTL $\left(R^{2}>10 \%\right)$ were identified associated with seed protein concentration. Of these QTL, seven QTL were detected in both populations, and eight of them were co-localized with QTL associated with either seed sucrose concentration or seed weight. None of the protein-related QTL was found to be associated with seed yield in either population. Sixteen candidate genes with putative roles in protein metabolism were identified within seven of these protein-related regions: qPro_Gm02-3, qPro_Gm04-4, qPro_Gm06-1, qPro_Gm06-3, qPro_Gm06-6, qPro_ Gm13-4 and qPro-Gm15-3.

Conclusion: The use of RIL populations derived from high-protein parents created an opportunity to identify four novel QTL that may have been masked by large-effect QTL segregating in populations developed from diverse parental cultivars. In total, we have identified nine protein QTL that were detected either in both populations in the current study or reported in other studies. These QTL may be useful in the curated selection of new soybean cultivars for optimized soy-based food products.
\end{abstract}

Keywords: Food-grade soybean, Protein, Sucrose, Seed weight, Linkage analysis, Candidate genes

\section{Background}

Soybean [Glycine $\max (\mathrm{L}$.) Merrill] is a major source of plant-based dietary protein. An increased demand for whole-bean soy-based food products, such as tofu and soymilk, in western countries has attracted the attention of researchers, soybean growers and soy-based food processors. Soy-based products require specific physical and chemical characteristics of the soybean seed, including optimal seed protein concentration, seed sucrose

\footnotetext{
* Correspondence: meskanda@uoguelph.ca
}

Department of Plant Agriculture, University of Guelph, Guelph, ON, Canada concentration and seed weight [1-7], that are not of importance to commodity soybean breeding programs. As food processors require consistent seed composition to maintain production procedures, the development of environmentally stable, high yielding soybean cultivars with optimal value-added traits has become an important breeding objective.

Seed composition and yield component traits are affected by numerous genes and environmental factors [8-13]. Seed protein concentration shares a welldocumented negative association with seed yield, which has hampered the development of competitive high-

(c) The Author(s). 2020 Open Access This article is licensed under a Creative Commons Attribution 4.0 International License, which permits use, sharing, adaptation, distribution and reproduction in any medium or format, as long as you give appropriate credit to the original author(s) and the source, provide a link to the Creative Commons licence, and indicate if changes were made. The images or other third party material in this article are included in the article's Creative Commons licence, unless indicated otherwise in a credit line to the material. If material is not included in the article's Creative Commons licence and your intended use is not permitted by statutory regulation or exceeds the permitted use, you will need to obtain permission directly from the copyright holder. To view a copy of this licence, visit http://creativecommons.org/licenses/by/4.0/. The Creative Commons Public Domain Dedication waiver (http://creativecommons.org/publicdomain/zero/1.0/) applies to the data made available in this article, unless otherwise stated in a credit line to the data. 
protein soybean cultivars [9, 14-23]. Additional valueadded traits, such as high seed sucrose concentration and high seed weight, are also of interest to soy-food processors. Sucrose concentration is known to influence the palatability and texture of many soy-food products [24]. However, seed protein and sucrose concentrations share a significant inverse relationship [25]. This relationship can be detrimental for soy-foods, such as tofu, that require high concentrations of both protein and sucrose for optimal production [5]. The identification and use of quantitative trait loci (QTL) associated with elevated seed protein concentration and additional valueadded traits could accelerate the development of competitive high-protein soybean cultivars for the North American food-grade market by accumulating desirable alleles into a common genetic background.

Numerous studies have sought to determine the genetic basis of seed protein accumulation in soybean. SoyBase has indexed 248 bi-parental QTL associated with seed protein concentration, which encompass the results of more than 35 independent studies [37]. These QTL are located on every soybean chromosome, although chromosomes 6, 15, 18 and 20 are particularly favoured [38]. A QTL-meta analysis conducted by Qi et al. [39] also identified 51 consensus QTL across numerous genetic backgrounds and growing environments, which were located on all linkage groups except Chromosome 16. Many factors, such as large confidence intervals, small additive effects, negative associations with other desirable traits, poor environmental stability and QTL-bygenetic background interaction effects, have limited the usefulness of these QTL in marker-assisted selection programs [40-44]. Numerous QTL have also been identified for other traits of interest, including 318 seed weight-related QTL identified in over 50 independent studies, and 188 seed yield-related QTL identified in 32 independent studies [37]. Sucrose concentration has received considerably less attention, with 37 sucroserelated QTL identified in 4 independent studies [37].

A global analysis of RNA-seq data revealed that Kunitz trypsin inhibitor 1 , lectin family proteins, seed storage $2 \mathrm{~S}$ albumin superfamily proteins, bZIP homologues and MYB-like transcription factors were associated with seed protein accumulation [39]. These transcripts were also associated with seed protein accumulation in previous studies [45-47]. Specific genes, such as $A B I 3, A B I 4$ and $L E C 1$ have also been associated with seed protein accumulation $[48,49]$.

One method of detecting QTL that may be of use in improving polygenic traits is to utilize segregating populations derived from elite parents [46]. Previous studies aimed at detecting protein-related QTL have mostly used mapping populations derived from exotic germplasm or parental cultivars with large phenotypic differences for the desired traits [50]. Utilizing populations derived from elite lines may increase the chance of detecting novel QTL that were masked by common large-effect QTL in diverse populations. These QTL have a higher chance of being beneficial for the development of new high-protein soybean cultivars.

In the present study, two recombinant inbred line (RIL) populations derived from crosses involving three high-yielding soybean cultivars with high to moderately high-protein content were used to identify QTL associated with traits important for food-grade soybean. Significant genomic regions associated with seed protein concentration were examined for their relationship with seed sucrose concentrations, seed weight and yield. Identifying genomic regions that underlie multiple valueadded traits would be beneficial for the simultaneous improvement of desirable traits in new food-grade soybean cultivars. To better understand the underlying mechanisms that regulate seed storage protein accumulation in soybeans, these regions were also screened for putative candidate genes.

\section{Results \\ Phenotypic analyses of protein and other value-added food-grade traits}

The RIL populations were evaluated for seed weight, yield, protein and sucrose concentrations in multienvironment trials during the 2015 and 2016 field seasons (Fig. 1; Supplementary Table S1-S4). Seed protein and sucrose concentrations were measured using the high-throughput near-infrared reflectance (NIR) method, which is now a common way of measuring seed composition traits in soybean [51, 52]. Although the highperformance liquid chromatography (HPLC) is a more accurate way for measuring seed sucrose content, previous studies showed that NIR methods can also generate reliable and unbiased estimates for soybean seed sucrose concentration that are suitable for discriminating genotypes with different levels of sucrose and also for QTL studies [52]. In this study, contrasts were noted for seed protein concentration between the parental cultivars in both populations. In POPn_1, 'AC X790P' had an average protein concentration of $48.08 \%( \pm 0.19 \%$, standard error) across the five testing environments, while 'S18R6' had an average of $40.93 \%$ ( $\pm 0.19 \%)$. In POPn_2. 'AC X790P' had an average protein concentration of $48.24 \%$ $( \pm 0.21 \%)$ across the five testing environments, while 'S23-T5' had an average of $42.60 \%$ ( $\pm 0.21 \%)$.

Differences in protein concentration between the RIL lines in each population were significant in the individual and combined multi-environment (Fig. 1; Supplementary Table S1). In POPn_1, seed protein concentration varied from 41.53 to $45.27 \%$, with an average protein concentration of $43.31 \%( \pm 0.03 \%)$. In 

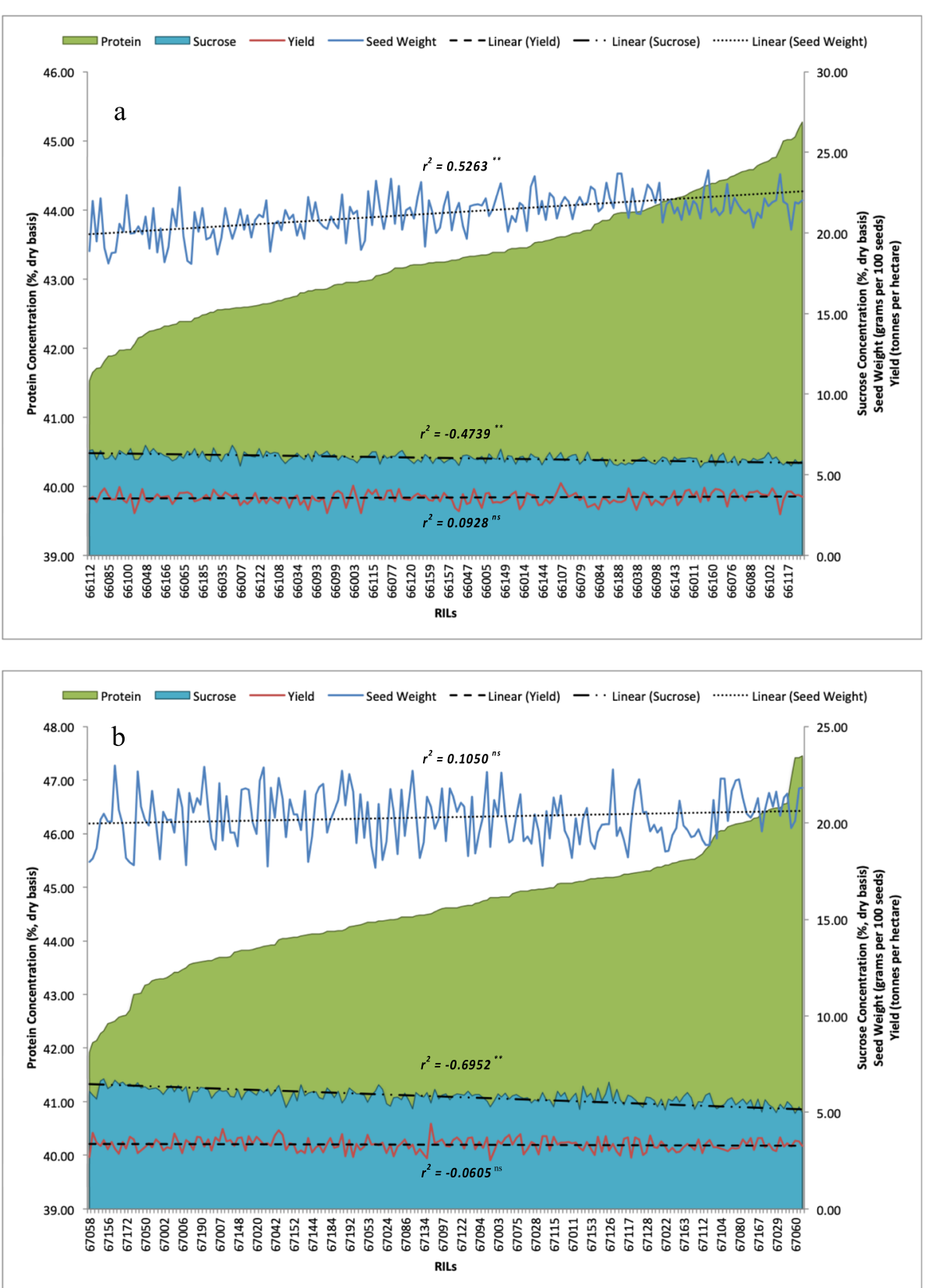

Fig. 1 Relationship between average protein and sucrose concentrations (\%, dry basis), seed weight (grams per 100 seeds) and seed yield (tonnes $\mathrm{ha}^{-1}$ ) in RIL populations derived from (a) 'AC X790P' x 'S18-R6' and (b) 'AC X790P' X 'S23-T5' examined under combined Ontario environments in 2015 and 2016. Trendlines depict the linear regression between protein concentration and each trait. Pearson correlation coefficients are also noted (** denotes $p<0.05 ;{ }^{\text {ns }}$ denotes a non-significant relationship

POPn 2, seed protein concentration varied from 41.93 to $47.46 \%$, with an average protein concentration of 44.60\% ( \pm 0.03\%) (Fig. 1; Supplementary Table S1). Transgressive segregation was observed in some individual environments but was not observed when the combined multi-environment data was considered (Supplementary Table S1). The normally distributed (Fig. 2) entry LSMEAN estimates indicate that protein concentration is controlled by multiple genes.
The parental cultivars also differed for seed yield, seed weight and seed sucrose concentration, and considerable variation was also noted within the combined multienvironment data for both populations (Fig. 1). In POPn_1, entry seed weight estimates (grams per 100 seeds) varied from $18.08 \mathrm{~g}$ to $23.88 \mathrm{~g}$, with an average seed weight of $21.18 \mathrm{~g}( \pm 0.055 \mathrm{~g})$. Seed yield also varied from $2.55 \mathrm{tha}^{-1}$ to $4.49 \mathrm{tha}^{-1}$, with an average seed yield of $3.57 \mathrm{tha}^{-1}\left( \pm 0.025 \mathrm{tha}^{-1}\right)$ and seed sucrose 


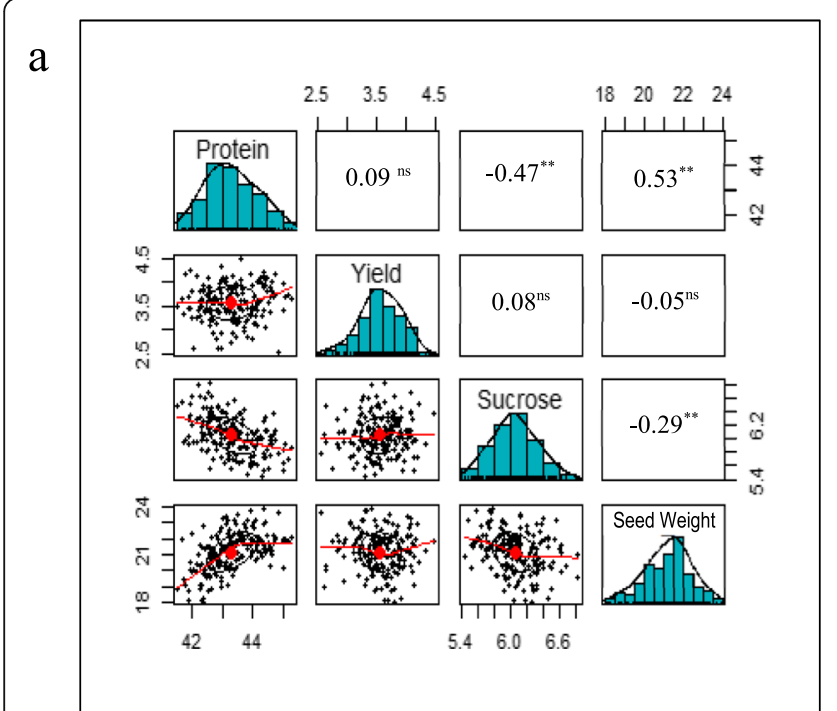

b

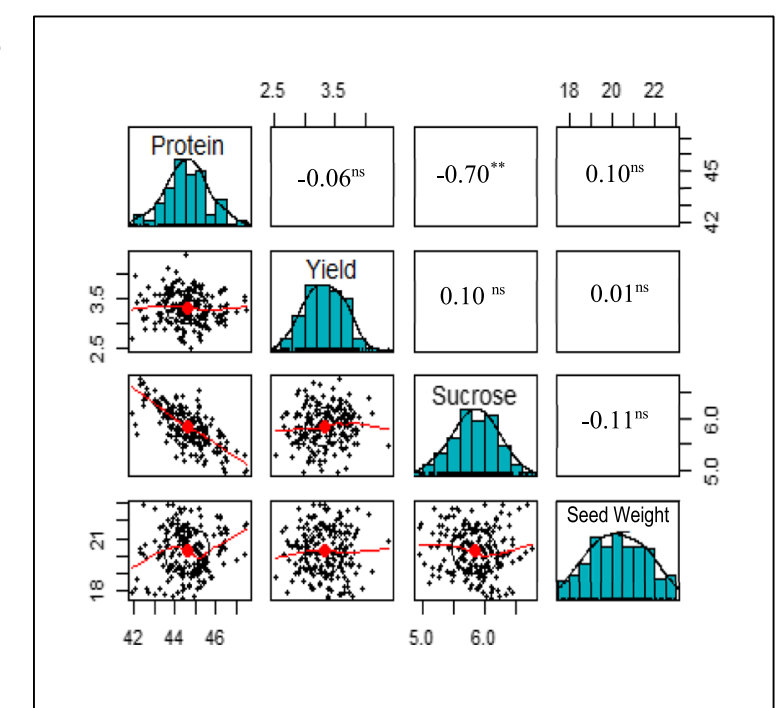

Fig. 2 Distribution of LSMEANs and Pearson correlation coefficients among important seed quality traits in two RIL populations examined under combined Ontario environments in 2015 and 2016: (a) 'AC X790P' X 'S18-R6' and (b) 'AC X790P' X 'S23-T5'

concentration varied from 5.44 to $6.82 \%$, with an average sucrose concentration of $6.06 \%( \pm 0.016 \%$; Supplementary Table S2-S4). Similar variability was noted in POPn_2 (Fig. 1). Seed weight varied from $17.67 \mathrm{~g}$ to $22.95 \mathrm{~g}$, with an average seed weight of $20.34 \mathrm{~g}( \pm 0.057 \mathrm{~g})$. Seed yield varied from $2.52 \mathrm{tha}^{-1}$ to $4.40 \mathrm{tha}^{-1}$, with an average seed yield of $3.34 \mathrm{t}$ $\mathrm{ha}^{-1}\left( \pm 0.024 \mathrm{tha}^{-1}\right)$ and seed sucrose concentration varied from 4.95 to $6.75 \%$, with an average sucrose concentration of $5.84 \% \quad( \pm 0.014 \%)$. Transgressive segregation was noted for seed yield and seed sucrose concentration in both populations. While some RILs exhibited transgressive segregation in individual environments for seed weight, this was not observed when the combined multi-environment data was considered (Supplementary Table S2-S4).

Our previous study revealed significant differences $(p<0.01)$ in genotype, environment, and genotype $\mathrm{x}$ environment treatments for protein concentration and yield in these populations [53], which indicates the important role of genetic factors on the performance of these target traits. High heritability was noted for protein concentration and 100-seed weight $\left(\mathrm{H}^{2}=0.93-0.95\right.$ and 0.87-0.89, respectively; Supplementary Table S5). Moderate heritability was observed for sucrose concentration $\left(\mathrm{H}^{2}=0.70-0.81\right.$; Supplementary Table S5), and low heritability was observed for seed yield $\left(\mathrm{H}^{2}=0.22-0.36\right)$ (Supplementary Table S5).

\section{Relationships between traits}

Pearson's correlation coefficients were used to determine the relationship between seed protein concentration and sucrose concentration, seed weight and yield in individual environments as well as combined multienvironment. Based on the combined multienvironment data, large, significant $(\alpha=0.05)$ negative correlations were observed between seed protein and sucrose concentration in both populations (POPn_1: $r=-0.47 ;$ POPn_2: $r=-0.70$; Fig. 2). In POPn_1, seed protein concentration and seed weight were positively correlated (POPn_1: $r=0.53$ ), and seed weight and sucrose concentration were negatively correlated (POPn_1: $r=-0.29)$. Interestingly, no significant relationships were noted between seed protein concentration and seed yield in either population (POPn_1: $\mathrm{r}=$ 0.09; POPn_2: $r=-0.06$ ) (Figs. 1 and 2). The linear relationship among the target agronomic and seed quality traits from individual environments are available in Supplementary Table S6.

\section{SNP mapping of the soybean genome}

Linkage maps were constructed from polymorphic SNP markers in each population. In POPn_1, a linkage map was created using 807 polymorphic SNP markers, and divided into 39 linkage groups. A linkage map consisting of 1406 SNP markers on 40 linkage groups was created on POPn_2. All 20 chromosomes in the soybean genome were represented, with most chromosomes consisting of two or more linkage groups. The linkage maps were 2385 and $2690 \mathrm{cM}$ in length for POPn_1 and POPn_2, respectively. The number of linkage groups was attributed to a lack of polymorphic markers between the parental genotypes distributed over large chromosomal regions, as elite Canadian soybean cultivars may share similar pedigrees. 
QTL associated with seed protein concentration

Using combined multi-environment data, 14 large-effect QTL were identified associated with seed protein concentration on Chromosomes 1, 2, 4, 5, 6, 8, 12, 13, 15 and 18. All the QTL were associated with protein in at least four individual environments. These 14 QTL explained between 10.4 and $21.9 \%$ of the observed phenotypic variation of seed protein concentration measured from combined multi-environment data (Table 1). Six of these QTL - qPro_Gm01-2, qPro_Gm04-3, qPro_Gm06-1, qPro_Gm06-3, qPro_Gm12-3, and qPro-Gm12-4 - carried the beneficial alleles from 'S18-R6' or 'S23-T5', while the remaining eight QTL - qPro_Gm02-3, qPro_Gm04-4, qPro-Gm05-2, qPro_Gm06-6, qPro-Gm08-2, qProGm13-4, qPro_Gm15-3, and qPro_Gm18-3 - carried the favorable alleles from 'AC X790P'. Positive protein-related QTL alleles in different genetic backgrounds suggests that it may be possible to stack favorable alleles to develop superior high-protein progeny.

Of the 14 QTL identified in this study, nine QTL qPro_Gm01-2 (R2 = 10.4\%), qPro-Gm04-4 (R2 = 13.7\%), qPro-Gm05-2 (R2 = 14.2\%), qPro_Gm06-1 (R2=21.9\%), qPro_Gm06-3 (R2 = 12.6\%), qPro_Gm08-2 ( $2=12.3 \%)$, qPro-Gm12-3 (R2=11.6\%), qPro-Gm12-4 ( $\mathrm{R} 2=12 \%)$, and qPro_Gm13-4 (R2=11.6\%) - were previously unreported and so are considered as novel QTL (Table 1; 26]. Four of these novel QTL were detected in both mapping populations (Table 1). The rest of the QTL that were co-localized with previously reported proteinrelated QTL on SoyBase are listed in Table 1; Supplementary Table S7.

\section{QTL associated with additional value-added traits}

Genomic regions harboring putative large-effect QTL associated with seed protein concentration were evaluated for their associations with seed yield, sucrose concentration, and seed weight using composite interval mapping analysis with the multiple QTL mapping (MQM) algorithm. (Table 2; Supplementary Table S8). Of the 14 protein-related QTL, eight QTL were co-localized with QTL associated with other traits. Three protein-related QTL - qPro_Gm01-2, qPro_Gm02-3, and qPro_Gm124 - were co-localized with QTL associated with seed sucrose concentration (Table 2). The favorable alleles were inherited from opposing parental sources for each of these genomic regions, which supports the significant negative relationship observed between seed protein and sucrose concentration in this study. (Table 2; Fig. 3). The remaining five protein-related QTL were associated with seed weight, with positive associations noted for three of these regions (Table 2; Fig. 3). Favourable alleles were donated by each parental cultivar for all traits-ofinterest. Protein-related QTL were not co-localized with significant regions for seed yield, consistent with the

Table 1 Major putative QTL ( $\left.\mathrm{R}^{2}>10.0 \%\right)$ associated with soybean seed protein concentration identified by multiple QTL mapping (MQM) in the two RIL populations ('AC X790P x S18-R6' and 'AC X790P x S23-T5') evaluated in five environments (CHA15, CHA16, MER15, MER16 and PAL16)

\begin{tabular}{|c|c|c|c|c|c|c|c|c|c|c|}
\hline QTL Name ${ }^{a}$ & Chr. & POPn & Flanking Markers & & Size (cM) & LOD $^{b}$ & $A^{c}$ & $\mathrm{R}^{2}(\%)$ & Source & References $^{d}$ \\
\hline qPro_Gm01-2 & 1 & 2 & S01_42371693 & S01_42555910 & 2.19 & 4.56 & 0.4578 & 10.4 & S23-T5 & - \\
\hline aPro_Gm02-3 & 2 & 1 & S02_40793724 & S02_41072417 & 4.58 & 5.16 & 0.4115 & 10.4 & AC X790P & VALSMA; $_{\text {S,2 }}$ \\
\hline qPro_Gmo4-3 & 4 & 2 & S04_44592458 & S04_45008840 & 1.64 & 5.25 & 0.4931 & 11.0 & S23-T5 & $2,3,11$ \\
\hline qPro_Gm04-4 & 4 & 1 & S04_48435528 & S04_49024162 & 14.21 & 6.03 & 0.3570 & 13.7 & AC X790P & - \\
\hline qPro_Gm05-2 & 5 & 1 & S05_38330071 & S05_38993543 & 12.31 & 6.80 & 0.4132 & 14.2 & AC X790P & VALSMA $_{S M}$ \\
\hline qPro_Gm06-1 & 6 & 1 & S06_19074 & S06_699413 & 1.68 & 10.19 & 0.4408 & 21.9 & S18-R6 & - \\
\hline qPro_Gm06-3 & 6 & 1 & S06_9128442 & S06_11029737 & 19.08 & 5.51 & 0.3339 & 12.6 & S18-R6 & VALSMA $_{\text {SM }}$ \\
\hline qPro_Gm06-6 & 6 & 1 & S06_30639643 & S06_33589987 & 0.28 & 5.80 & 0.3046 & 13.2 & AC X790P & $2,5,6,7$ \\
\hline qPro_Gm08-2 & 8 & 1 & S08_43864875 & S08_43896183 & 2.25 & 5.38 & 0.3936 & 12.3 & AC X790P & $\mathrm{VAL}_{\text {SMA }}$ \\
\hline qPro_Gm12-3 & 12 & 1 & S12_924424 & S12_1147989 & 11.46 & 6.45 & 0.4943 & 11.6 & S18-R6 & - \\
\hline aPro_Gm12-4 & 12 & 1 & S12_3518939 & S12_3666689 & 7.64 & 6.63 & 0.4757 & 12.0 & S18-R6 & - \\
\hline qPro_Gm13-4 & 13 & 2 & S13_28227783 & S13_28254683 & 4.46 & 8.54 & 2.2804 & 11.6 & AC X790P & $\mathrm{VAL}_{\text {SMA }}$ \\
\hline qPro_Gm15-3 & 15 & 2 & S15_10218629 & S15_10877491 & 1.64 & 5.63 & 0.6925 & 11.5 & AC X790P & $\operatorname{VAL}_{S M A} ; 4,8,9,10$ \\
\hline qPro_Gm18-4 & 18 & 1 & S18_52660341 & S18_53019901 & 18.54 & 4.50 & 0.2713 & 10.4 & AC X790P & $\mathrm{VAL}_{\mathrm{SMA}} ; 2$ \\
\hline
\end{tabular}

${ }^{a} \mathrm{QTL}$ for the same trait detected in all individual environments (CHA15, CHA16, MER15, MER16 and PAL16) and the combined environment (GMET) with the same or overlapping marker interval was designated as one QTL. QTL highlighted in bold are novel QTL and were validated in the other RIL population ${ }^{b}$ LOD thresholds were calculated through a permutation test with 1000 iterations and a Type I error rate of 0.001

'Additive effects calculated as the absolute value of half the subtraction of the mean of genotypes with the 'S18-R6' ('POPn_1') or 'S23-T5' (POPn_2) allele (negative effect) from the mean of genotypes with the 'AC X790P' allele (positive allele)

${ }^{\mathrm{d}}$ Indicating that the QTL was confirmed in the other RIL population through multiple QTL mapping $\left(V^{2} L_{M O M}\right)$, single marker analysis $(V A L S M A)$, and/or has been reported previously in the reference(s): 1. [31] 2. [30] 3. [32] 4. [28] 5. [34] 6. [36] 7. [35] 8. [26] 9. [29] 10. [27].11. [33] 
Table 2 Putative QTL for additional food-grade traits of interest (seed yield, seed weight and sucrose concentration) associated with major seed protein concentration QTL identified by multiple QTL mapping (MQM) in a RIL population derived from 'AC X790P $x$ S18-R6' and 'AC X790P x S23-T5' examined under combined Ontario environments from 2015 and 2016

\begin{tabular}{|c|c|c|c|c|c|c|c|c|c|c|c|}
\hline \multirow{2}{*}{$\frac{\text { Protein QTL }}{\text { qPro_Gm01-2 }}$} & \multirow{2}{*}{$\frac{\text { QTL Name }^{\text {a }}}{\text { qSuc_Gm01-2 }}$} & \multirow{2}{*}{$\begin{array}{l}\text { Chr. } \\
1\end{array}$} & \multirow{2}{*}{$\frac{\text { POPn }}{2}$} & \multicolumn{2}{|c|}{ Flanking Markers } & \multirow{2}{*}{$\frac{\text { Size (cM) }}{2.19}$} & \multirow{2}{*}{$\frac{\text { LOD }^{\mathbf{b}}}{6.67}$} & \multirow{2}{*}{$\begin{array}{l}A^{\mathbf{c}} \\
0.1472\end{array}$} & \multirow{2}{*}{$\begin{array}{l}\mathbf{R}^{\mathbf{2}} \text { (\%) } \\
14.5\end{array}$} & \multirow{2}{*}{$\frac{\text { Source }}{A C \times 790 P}$} & \multirow{2}{*}{$\begin{array}{l}\text { Relationship } \\
\text { Inverse }\end{array}$} \\
\hline & & & & S01_42371693 & S01_42555910 & & & & & & \\
\hline qPro_Gm02-3 & qSuc_Gm02-3 & 2 & 2 & S02_40716331 & S02_42411031 & 11.17 & 5.46 & 0.1993 & 10.7 & S23-T5 & Inverse \\
\hline qPro_Gm05-2 & qWt_Gm5-2 & 5 & 2 & S05_38273700 & S05_38764985 & 1.94 & 3.98 & 1.2482 & 8.1 & S23-T5 & Inverse \\
\hline qPro_Gm06-1 & qWt_Gm6-1 & 6 & 1 & S06_19074 & S06_798961 & 2.24 & 4.46 & 0.3927 & 10.3 & S18-R6 & Positive \\
\hline qPro_Gm06-6 & qWt_Gm6-3 & 6 & 1 & S06_30639643 & S06_33589987 & 0.28 & 4.20 & 0.3754 & 9.4 & AC X790P & Positive \\
\hline qPro_Gm08-2 & qWt_Gm8-2 & 8 & 1 & S08_43325761 & S08_43864912 & 17.39 & 4.29 & 0.5042 & 9.6 & AC X790P & Positive \\
\hline qPro_Gm12-4 & qSuc_Gm12-1 & 12 & 1 & S12_3518939 & S12_3666689 & 7.64 & 5.49 & 0.1495 & 12.4 & AC X790P & Inverse \\
\hline qPro_Gm15-3 & qWt_Gm15-4 & 15 & 2 & S15_10731054 & S15_11188445 & 3.33 & 2.78 & 0.8428 & 5.3 & AC X790P & Positive \\
\hline
\end{tabular}

${ }^{a}$ QTL for the same trait detected in all individual environments (CHA15, CHA16, MER15, MER16 and PAL16) and the combined environment (GMET) with the same or overlapping marker interval was designated as one QTL

${ }^{b}$ LOD thresholds were calculated through a permutation test with 1000 iterations and a Type I error rate of 0.001

'Additive effects calculated as the absolute value of half the subtraction of the mean of genotypes with the 'S18-R6' ('POPn_1') or 'S23-T5' (POPn_2) allele

(negative effect) from the mean of genotypes with the 'AC X790P' allele (positive allele)

non-significant relationship between seed protein concentration and seed yield in both populations. SoyBase associated seven of our protein-related QTL with previously identified QTL for seed weight (nine QTL), seed oil concentration (five QTL) and seed yield (two QTL) (Supplementary Table S7 [37].

\section{Candidate genes mining within protein QTL region}

For further validation of the QTL identified as associated with seed protein concentration, a list of candidate genes was compiled using the Glyma 2.0 Assembly of Williams 82 on SoyBase (Wm82.a2.v1) according to their functional knowledge [37]. The number of genes in each

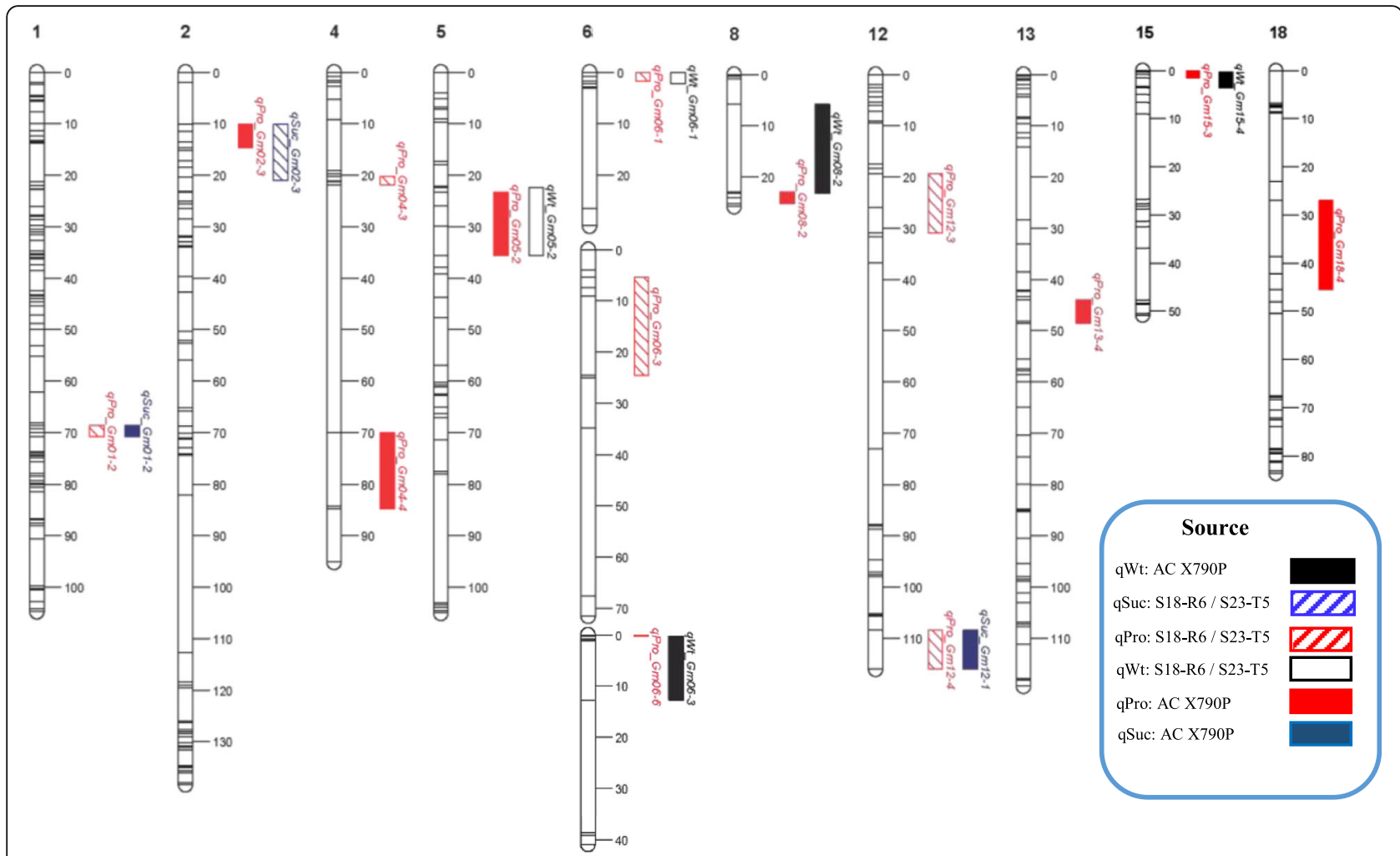

Fig. 3 Graphical representation of putative QTL identified using multiple QTL mapping (MQM) algorithms for seed protein and sucrose concentrations, and seed weight in the two RIL populations: 'AC X790P' X 'S18-R6' and 'AC X790P' X 'S23-T5'. Positive allele source is denoted by block pattern: 'AC X790P' is represented by a solid pattern, while 'S18-R6' and 'S23-T5' are represented by a striped pattern. Traits of interest are denoted by colour: seed protein concentration (red), seed sucrose concentration (navy) and seed weight (black) 
QTL flanking region varied from four to seventy-four. In the flanking region corresponding to qPro_Gm13-4 (spanning $26 \mathrm{~kb}$ ), five genes were identified. These genes include Glyma.13G167800 and Glyma.13G167900, which are located 6 and $9 \mathrm{~kb}$ downstream of the SNP peak (28246299) and are annotated as a ribosomal protein and a ribosome biogenesis regulatory protein, respectively (Table 3 ). These genes have an indirect role in protein synthesis. Gene expression data provided by Severin et al. [54] noted that Glyma.13G167800 is expressed in the seed from 10 to 21 day after flowering (DAF). Glyma.13G167900 is also expressed in the seed albeit at a lower level compared to Glyma.13G167800. Two candidate genes, Glyma.06G004500 and Glyma.06G001800, underlying qPro_Gm06-1 were identified. These genes, located in $74 \mathrm{~kb}$ upstream and $148 \mathrm{~kb}$ downstream of the QTL peak, respectively, encode transmembrane amino acid transporter proteins and ribosomal family proteins and (Table 3). Previous transcriptomic analyses noted increased expression of Glyma.06G004500 in the seed at 14 to 17 , and 21 DAF [54].

Glyma.04G212500 and Glyma.04G214500 were identified under qPro_Gm04-4 intervals. These genes are associated with the cupin superfamily and ribosomal protein family, respectively (Table 3 ). The cupin superfamily is involved in seed storage protein [55], while ribosomal protein family genes are associated with mRNA translation. In addition, candidate gene Glyma.04212500 are located exactly in the SNP peak position, which support the role of cupin associated with seed protein concentration. Glyma.06G113700, Glyma.06G116400, and Glyma.06G119700 were located in qPro_Gm06-3 region (Table 3). Glyma.06G113700 encodes a potential structural constituent of $40 \mathrm{~S}$ ribosomal

Table 3 Major putative QTL $\left(R^{2}>10.0 \%\right)$ and candidate genes identified in confidence intervals of QTL associated with soybean seed protein concentration in the two RIL populations ('AC X790P x S18-R6' and 'AC X790P x S23-T5')

\begin{tabular}{|c|c|c|c|c|c|c|c|}
\hline $\begin{array}{l}\text { QTL } \\
\text { Name }^{\text {a }}\end{array}$ & Chr. & Flanking Markers & Candidate ID & Annotation & Type & Description & Position \\
\hline \multirow[t]{2}{*}{$\begin{array}{l}\mathrm{qPrO}_{-} \\
\mathrm{GmO2-3}\end{array}$} & 2 & $\begin{array}{l}\text { S02_40793724- S02_ } \\
41072417\end{array}$ & $\begin{array}{l}\text { Glyma.02 } \\
\text { g220000 }\end{array}$ & GO:0006412 & $\begin{array}{l}\mathrm{GO}- \\
\mathrm{bp}\end{array}$ & 60S Ribosomal protein L16p/L10e & $\begin{array}{l}40,794 \\
106.40795066\end{array}$ \\
\hline & & & $\begin{array}{l}\text { Glyma.02 } \\
\text { g221500 }\end{array}$ & GO:0006412 & $\begin{array}{l}\text { GO- } \\
\mathrm{bp}\end{array}$ & 30 S Ribosomal protein S2 & $\begin{array}{l}40,921 \\
208.40921756\end{array}$ \\
\hline \multirow[t]{2}{*}{$\begin{array}{l}\text { qPro }_{-} \\
\text {Gm04-4 }\end{array}$} & 4 & $\begin{array}{l}\text { S04_48435528 - S04_ } \\
49024162\end{array}$ & $\begin{array}{l}\text { Glyma.04 } \\
\text { g212500 }\end{array}$ & AT5G61750 & AT & Cupin & $\begin{array}{l}48,435 \\
108 . .48435965\end{array}$ \\
\hline & & & $\begin{array}{l}\text { Glyma.04 } \\
\text { g214500 }\end{array}$ & GO:0006412 & $\begin{array}{l}\text { GO- } \\
\mathrm{bp}\end{array}$ & Ribosomal protein L17 family protein & \\
\hline \multirow[t]{2}{*}{$\begin{array}{l}q^{q P r O} \\
\text { Gm06-1 }\end{array}$} & 6 & S06_19074 - S06_699413 & $\begin{array}{l}\text { Glyma.06 } \\
\text { g004500 }\end{array}$ & GO:0015171 & $\begin{array}{l}\text { GO- } \\
\mathrm{mf}\end{array}$ & $\begin{array}{l}\text { Transmembrane amino acid transporter } \\
\text { protein }\end{array}$ & $393,722 . .398436$ \\
\hline & & & $\begin{array}{l}\text { Glyma.06 } \\
\text { g001800 }\end{array}$ & GO:0006412 & $\begin{array}{l}\text { GO- } \\
\mathrm{bp}\end{array}$ & $\begin{array}{l}\text { Ribosomal protein L3 family protein/ } \\
\text { Translation protein }\end{array}$ & $171,462 . .172334$ \\
\hline \multirow[t]{3}{*}{$\begin{array}{l}\text { aPro } \\
\text { Gm06-3 }\end{array}$} & 6 & $\begin{array}{l}\text { S06_9128442 - S06_ } \\
11029737\end{array}$ & $\begin{array}{l}\text { Glyma.06 } \\
\text { g113700 }\end{array}$ & GO:0006412 & $\begin{array}{l}\mathrm{GO}- \\
\mathrm{bp}\end{array}$ & 40S ribosomal protein S3a-like & $\begin{array}{l}9,225 \\
152 . .9227191\end{array}$ \\
\hline & & & $\begin{array}{l}\text { Glyma.06 } \\
\text { g116400 }\end{array}$ & PF01490 & PFAM & $\begin{array}{l}\text { Transmembrane amino acid transporter } \\
\text { protein }\end{array}$ & $\begin{array}{l}9,472 \\
699 . .9476835\end{array}$ \\
\hline & & & $\begin{array}{l}\text { Glyma.06 } \\
\text { g119700 }\end{array}$ & GO:0006886 & $\begin{array}{l}\text { GO- } \\
\mathrm{bp}\end{array}$ & Intracellular protein transport & $\begin{array}{l}9,737 \\
256 . .9743653\end{array}$ \\
\hline \multirow[t]{2}{*}{$\begin{array}{l}\text { qPro_}_{-} \\
\text {Gm06-6 }\end{array}$} & 6 & $\begin{array}{l}\text { S06_30639643 - S06_ } \\
33589987\end{array}$ & $\begin{array}{l}\text { Glyma.06 } \\
\text { g225600 }\end{array}$ & GO:0006413 & $\begin{array}{l}\text { GO- } \\
\mathrm{bp}\end{array}$ & Translation initiation & $\begin{array}{l}31,131 \\
372.31133932\end{array}$ \\
\hline & & & $\begin{array}{l}\text { Glyma.06 } \\
\text { g225700 }\end{array}$ & GO:0006412 & $\begin{array}{l}\mathrm{GO}- \\
\mathrm{bp}\end{array}$ & Translation initiation factor elF-4F & $\begin{array}{l}31,209 \\
402.31216702\end{array}$ \\
\hline \multirow[t]{2}{*}{$\begin{array}{l}\text { aPro } \\
\text { Gm13-4 }\end{array}$} & 13 & $\begin{array}{l}\text { S13_28227783 - S13_ } \\
28254683\end{array}$ & $\begin{array}{l}\text { Glyma.13 } \\
\text { g167800 }\end{array}$ & GO:0042254 & $\begin{array}{l}\text { GO- } \\
\mathrm{bp}\end{array}$ & Ribosome biogenesis & $\begin{array}{l}\text { 28,237, } \\
788.28239022\end{array}$ \\
\hline & & & $\begin{array}{l}\text { Glyma.13 } \\
\text { g167900 }\end{array}$ & GO:0042254 & $\begin{array}{l}\text { GO- } \\
\mathrm{bp}\end{array}$ & Ribosome biogenesis regulatory protein & $\begin{array}{l}28,240 \\
381.28243803\end{array}$ \\
\hline \multirow[t]{3}{*}{$\begin{array}{l}\text { aPro } \\
\text { Gm15-3 }\end{array}$} & 15 & $\begin{array}{l}\text { S15_10218629-S15_ } \\
10877491\end{array}$ & $\begin{array}{l}\text { Glyma.15 } \\
\text { g129800 }\end{array}$ & GO:0006412 & $\begin{array}{l}\text { GO- } \\
\mathrm{bp}\end{array}$ & Ribosomal protein S27a/Ubiquitin family & $\begin{array}{l}10,430 \\
457 . .10431571\end{array}$ \\
\hline & & & $\begin{array}{l}\text { Glyma. } 15 \\
\text { g130000 }\end{array}$ & GO:0006412 & $\begin{array}{l}\mathrm{GO}- \\
\mathrm{bp}\end{array}$ & Structural constituent of ribosome & $\begin{array}{l}\text { 10,439, } \\
067 . .10440332\end{array}$ \\
\hline & & & $\begin{array}{l}\text { Glyma.15 } \\
\text { g134800 }\end{array}$ & GO:0006412 & $\begin{array}{l}\text { GO- } \\
\mathrm{bp}\end{array}$ & Ribosomal protein L7/L12 C-terminal domain & $\begin{array}{l}\text { 10,831, } \\
146 . .10833232\end{array}$ \\
\hline
\end{tabular}


protein. Glyma.06G116400 and Glyma.06G119700 were associated with a transmembrane amino acid transporter protein and an intracellular transport protein, respectively (Table 3).

Three candidate genes, Glyma.15G129800, Glyma.15G130000, and Glyma.15G134800, were identified from qPro_Gm15-3 which are involved in structural constituents of the ribosome (Table 3). Moreover, Glyma.06G225600 and Glyma.06G225700, which were annotated as translation initiation factor proteins were identified under qPro_Gm06-6 intervals (Table 3). Glyma.02G220000 and Glyma.02G221500, which contribute to the structural integrity of the ribosome and play a role in translation were located in qPro_GmO2-3 region (Table 3). Based on previous transcriptomic analyses, Glyma.02G220000 is expressed in the seed 14 to 17,21 , 25, 28 and 35 DAF [54].

Candidate genes were also postulated for sucrose- and seed weight-related QTL that co-localized with proteinrelated regions. Four candidate genes were identified: Glyma.06G004400 and Glyma.06G007900, which were located under qPro_Gm06-1 and qWt_Gm06-1 region, and Glyma.15G133600 and Glyma.15G133800 that were located under qPro_Gm15-3 and qWt_Gm15-4 region. All four genes are involved in carbohydrate metabolism (GO:0005975) (Table 4).

\section{Discussion}

Soy-based food manufacturers require specific physical and chemical characteristics of the soybean seed to maintain their production practices. For example, optimal tofu production requires high concentrations of both protein and sucrose in the soybean seed. However, protein and sucrose concentration have a negative relationship [38, 52, 56-58]. These significant negative relationships between seed protein concentration and other value-added traits have been major deterrents to the development of competitive foodgrade soybean cultivars through conventional breeding methods [14-23, 59]. The identification of proteinrelated QTL that has no effect on sucrose or has a positive impact on other value-added traits would be of major benefit. The relationship between seed protein concentration, seed weight and yield in our study indicated that both current populations are desirable for the selection of optimal protein concentration with competitive yield and large seed size. On the other hand, negative relationship between seed protein and sucrose concentration indicated the selection for protein concentration may occur at the expense of seed sucrose concentration (and vice versa). These relationships could be attributed to tightly linked loci governing these traits separately, or to pleiotropic effects of specific loci [19].

Broad-sense heritability estimations in current study confirmed that a large proportion of the observed phenotypic variation for seed protein concentration, seed sucrose concentration, and seed weight are attributed to genotype. Therefore, phenotypic selection may be a successful tool to increase genetic gain for these traits. This is consistent with previous studies, in which moderate to high heritability estimates have been reported for seed protein concentration $\left(\mathrm{H}^{2}=0.81-0.92 ;[16,60]\right.$, seed sucrose concentration $\left(\mathrm{H}^{2}=0.46-0.86 ;[60,61]\right.$ and seed weight $\left(\mathrm{H}^{2}=0.73-0.89 ; \quad[60]\right.$ across different genetic backgrounds and environments.

It is possible to 'stack' desirable QTL for multiple traits of interest using MAS, which allows breeders to screen early generation material for optimal trait combinations. This approach has been utilized breeding programs, especially for breeding disease resistance cultivars [62-64]. Maroof et al. [65] discussed the value of pyramiding race-specific soybean mosaic virus resistance genes using MAS, which involved the curation of specific genetic combinations for optimal multiple resistance. This approach increased the ability of the breeding program to select homozygous plants with multiple resistance, as the epistatic interactions among disease resistance genes made the phenotypic screening of disease reaction unreliable [65]. This strategy was also utilized by Jiang et al. [66], where the pyramiding of positive alleles from different parental sources was shown to

Table 4 Major putative QTL $\left(R^{2}>10.0 \%\right)$ and candidate genes identified in confidence intervals of QTL associated with soybean seed protein concentration which co-located with seed weight or sucrose concentration in the two RIL populations ('AC X790P $x$ S18-R6' and 'AC X790P x S23-T5')

\begin{tabular}{|c|c|c|c|c|c|c|c|}
\hline Protein QTL & QTL Name & Chr. & Flanking Markers & Candidate ID & Annotation & Description & Position \\
\hline \multirow[t]{2}{*}{$\begin{array}{l}\text { qPro_Gm06- } \\
1\end{array}$} & qWt_Gm6-1 & 6 & S06_19074 - S06_798961 & $\begin{array}{l}\text { Glyma.06 } \\
\text { g004400 }\end{array}$ & GO:0005975 & $\begin{array}{l}\text { Carbohydrate } \\
\text { metabolism }\end{array}$ & $380,973 . .384365$ \\
\hline & & & & $\begin{array}{l}\text { Glyma.06 } \\
\text { g007900 }\end{array}$ & GO:0005975 & $\begin{array}{l}\text { Carbohydrate } \\
\text { metabolism }\end{array}$ & $613,002 . .614426$ \\
\hline \multirow[t]{2}{*}{$\begin{array}{l}\text { qPro_Gm15- } \\
3\end{array}$} & $\begin{array}{l}\text { qWt_Gm15- } \\
4\end{array}$ & 15 & $\begin{array}{l}\text { S15_10731054-S15_ } \\
11188445\end{array}$ & $\begin{array}{l}\text { Glyma.15 } \\
\text { g133600 }\end{array}$ & GO:0005975 & $\begin{array}{l}\text { Carbohydrate } \\
\text { metabolism }\end{array}$ & $\begin{array}{l}\text { 10,739, } \\
528 . .10743270\end{array}$ \\
\hline & & & & $\begin{array}{l}\text { Glyma.15 } \\
\text { g133800 }\end{array}$ & GO:0005975 & $\begin{array}{l}\text { Carbohydrate } \\
\text { metabolism }\end{array}$ & $\begin{array}{l}10,754 \\
838.10756823\end{array}$ \\
\hline
\end{tabular}


increase seed protein filling rate and overall seed quality in soybean.

In this study, 14 large-effect QTL associated with seed protein concentration were identified, with the positive alleles derived from each of the parental sources. This may be attributed to the unique mapping populations utilized in this study. Previous QTL studies have used mapping populations that were derived from exotic germplasm or parental cultivars with large phenotypic differences for the desired trait-of-interest [50]. However, many modern elite soybean cultivars already possess high protein concentrations (approximately $40 \%$, dry basis) and may be fixed for the large-effect QTL identified in diverse populations. In the current study, the utilization of moderate- and highprotein elite parental cultivars allowed for the identification of novel QTL that may have been masked in other populations $[60,67,68]$ and also result in two or more linkage groups in most of chromosomes and the absence of major QTL regions associated with seed protein concentration, such as those on Chromosomes 15 and 20. The elimination of these regions may have also restricted the full scope of QTL interactions in these populations, and exaggerated the influence of the identified QTL on the traits-of-interest [67, 69, 70]. Additionally, many QTL mapping procedures have difficulty with the identification of small and intermediate effect QTL. These small and intermediate QTL are primarily associated with quantitative traits, such as seed protein concentration [71, 72]. The Beavis effect suggests that estimates of phenotypic variance may be greatly overestimated in smaller mapping populations $(<1000$ progeny; 61$)$, which may have further exaggerated the influence of the identified QTL in this study.

Recently, Hagely et al. [73] utilized direct molecularassisted selection to improve the carbohydrate composition of soybean seeds. A natural variant of the raffinose synthase 3 gene (rs3 snp5) was associated with an ultra-low raffinose family oligosaccharide (UL RFO) carbohydrate profile, which improved the sucrose concentration and available metabolized energy of the soybean meal $[74,75]$. The reduction in raffinose and stachyose was attributed to a specific genetic combination - rs 2 W331 + rs 3 snp $5 / r s 3 \operatorname{snp} 6$ haplotype $\mathrm{C}$ - that results from a defect in the RS3 gene. Molecular marker assays were developed to detect these variants, which streamlined their introgression into elite soybean cultivars [73].

In an effort to further understand the underlying mechanisms of protein concentration in the soybean seed, candidate genes were identified from the flanking regions of our protein-related QTL and screened for their functional role in protein accumulation. In this study, 491 genes were identified and grouped using their biological process and functional annotation in SoyBase (www.soybase.org; [76]). Numerous putative candidate genes were identified (Table 4) through GO annotation:
16 genes were associated with protein translation processes (GO:0006412, GO:0015171, GO:0006413, GO: 0042254, GO:0006886, AT6G61750, and PF01490), eight genes were associated with carbohydrate metabolism (GO:0005975), three genes were associated with lipid metabolism (GO:0006629), and the remainder were involved in signal transduction, transport, biosynthetic processes, nucleic acid metabolism, photosynthesis and numerous other functions. The significant relationships between protein, oil and sucrose $[38,52,55,57]$ support the role of genes associated with lipid and carbohydrate metabolism, which were also identified in the flanking region of these protein-related QTL.

Transcriptome analysis data provided by Severin et al., [54] showed Glyma.13G167800 (ribosome biogenesis), Glyma.13G167900 (ribosome biogenesis), Glyma.06G004500 (transmembrane amino acid transporter protein) and Glyma.02G220000 (60S ribosomal protein) are expressed in the seed, which supports their role in soybean seed protein accumulation. Glyma.04G212500 was associated with the cupin superfamily, which includes the $11 \mathrm{~S}$ (glycine) and 7S (ß-conglycinin) seed storage proteins. 11S and $7 \mathrm{~S}$ seed storage proteins account for $\sim 70 \%$ of storage proteins within the soybean seed [54, 77]. Therefore, Glyma.04G212500 may have a strong association with seed protein accumulation in soybean. Zhang et al. [78] identified 13 candidate genes with putative roles in protein biosynthesis on Chromosome 15 and 20, with functional annotation of a structural constituent of ribosome, 60S ribosomal protein, amino acid transmembrane transport, and translation initiation factor 3. These annotations were also associated with seven candidate genes in our study, which strongly supports their role in protein accumulation in our populations. Zhang et al. [78] also conducted gene expression analyses of ribosomal, translation initiation factor 3 and amino acid transmembrane transport genes, which showed significant up-regulation of expression in the high-protein parent during the reproductive growth stage in the pod. This is consistent with their role in protein accumulation in soybean seeds [78]. Li et al. [79] also found a candidate gene in the flanking region of a protein QTL on chromosome 9, which was annotated as an amino acid transporter gene. In another study, the overexpression of one amino acid transporter gene in Vicia narbonensis and pea resulted in significant increases in seed protein concentration [80]. Further exploration of these candidate genes and their possible variants would further our understanding of protein accumulation pathways in the soybean seed and may lead to improved marker- or molecular-assisted breeding techniques for the improvement of soybean seed composition traits. 


\section{Conclusion}

In summary, nine of the protein-related QTL identified in this study were validated and may be suitable for marker assisted selection programs. Each provide vital information for the simultaneous improvement of multiple traits. Their value will be dictated by the objective of the individual breeding program. For example, qPro Gm06-1, qPro_Gm06-6, qPro_Gm08-2, and qPro_ Gm15-3 were positively associated with seed weight QTL. These QTL may be unsuitable for a natto breeding program, which would favour smaller seed size. In this case, qPro_Gm05-2 - a protein-related QTL inversely associated with seed weight - would be preferable. A curated panel of multiple-trait QTL may allow breeders to screen early-generation germplasm for the specific physical and chemical characteristics required by soy-food processors.

Future studies may look to consider the impact of protein biosynthesis, storage and metabolism on seed protein concentration in soybean, as suggested by the postulated candidate gene functions noted in this study, to foster a better understanding of protein accumulation pathways in the soybean seed. Breeders may also wish to dive deeper and explore the potential variants of these candidate genes, and their role in plant metabolism. The QTL presented in this study are offered as a tool for food-grade soybean breeding programs utilizing markerassisted selection, and as a starting point for the discovery of variants in the protein biosynthesis pathway.

\section{Methods}

\section{Mapping populations}

Two populations of $\mathrm{F}_{4}$-derived recombinant inbred lines (RILs) were used to identify putative quantitative trait loci (QTL) for seed composition traits and yield. The first population (POPn_1) consisted of 190 RILs derived from a cross between 'AC X790P' and 'S18-R6'. 'AC $\mathrm{X790P}$ ' is a 2.2 relative maturity group (MG) cultivar developed by Agriculture and Agri-Food Canada in Harrow, Ontario, with a high, stable seed protein concentration (48.6\%, dry weight basis; [49]). 'S18-R6' is a 1.8 MG commercial cultivar with a moderate seed protein concentration (40.4\%), developed by Syngenta Canada, Inc. in Arva, Ontario [81].

The second population (POPn_2) was comprised of 193 RILs from a cross between 'S23-T5' and 'AC X790P'. 'S23-T5' is a high-yielding 2.3 MG elite cultivar with moderate seed protein $(41.3 \%)$ developed by Syngenta Seeds, Inc. in Owatonna, Minnesota [82]. Parental cultivars were considered high yielding when compared to the historical yield for southwestern Ontario [83]. Both RIL populations were developed at the University of Guelph, Ridgetown Campus.

\section{Experimental design}

The RIL populations were grown in five environments across southwestern Ontario in 2015 and 2016: Chatham 2015 (CHA15), Merlin 2015 (MER15), Chatham 2016 (CHA16), Merlin 2016 (MER16) and Palmyra 2016 (PAL16). Field trials were planted using randomized complete block designs with two replications, in which the plot performance was adjusted for spatial variability through nearest neighbour analysis (NNA) using information from the immediate neighbouring plots in each of the five environments [53]. Plots consisted of five 4-m rows with $43-\mathrm{cm}$ row spacing and were trimmed to 3.8 $\mathrm{m}$ in length following emergence. Plots were seeded at a rate of 69 seeds $/ \mathrm{m}^{2}$ or 500 seeds per plot. Trials were maintained using standard tillage and cultural practices, and the three center rows of each plot were harvested for seed yield estimation and post-harvest evaluations.

\section{Phenotypic data collection}

Seed protein and sucrose concentrations were determined for each harvested plot using a Perten DA 7250 SD near-infrared reflectance (NIR) analyzer (Perten Instruments Canada, Winnipeg, MB) using calibrations provided by Perten Instruments [84-87]. The calibration statistics for different seed composition traits, including seed protein and sucrose concentrations, are provided in Supplementary Table S9. Each NIR measurement is an average of three technical replications. Seed yield (tonnes ha ${ }^{-1}$ at $13 \%$ moisture) and seed weight (grams per 100 seeds) were also recorded for each harvested plot.

\section{Statistical analyses}

Statistical analyses were performed using SAS 9.4 (SAS Institute Inc., Cary, NC). An analysis of variance (ANOVA) was conducted and PROC MIXED was used to generate LSMEANS for each environment with 'genotype' as a fixed effect and 'block' as a random effect. PROC MIXED was also used to perform combined ANOVAs for seed weight, and protein and sucrose concentrations using the model:

$$
Y_{i j}=\mu+\alpha_{i}+\beta_{j}+\alpha \beta_{i j}+\varepsilon_{i j}, j=1, \ldots, n ; i=1, \ldots, k
$$

where $Y_{i j}$ represented the trait of interest (seed protein accumulation, seed sucrose accumulation, seed weight or seed yield), $\alpha_{i}$ represents the 'genotype' effect, $\beta_{j}$ represents the 'environment' effect, $\alpha \beta_{i j}$ represents the 'genotype-by-environment' effect and $\varepsilon_{i j}$ represented the residual effect. 'Genotype', 'environment' and 'genotypeby-environment' were considered fixed effects and 'block(environment)' was considered a random effect. PROC CORR was used to examine the relationships between entry trait estimates. 


\section{Genotypic data collection}

Young trifoliate leaf tissue was collected from the first replicate block of each population at the Palmyra 2016 location. Leaf tissue for each RIL was sampled from multiple plants in each plot and stored in $2 \mathrm{~mL}$ screw cap tubes. The samples were freeze-dried for 72 -h using a Savant ModulyoD Thermoquest (Savant Instruments, Holbrook, NY), and then stored at $-80^{\circ} \mathrm{C}$ for future use. Genomic DNA was extracted from the freeze-dried tissue samples using a modified procedure from the Sigma GenElute $^{\text {mI }}$ DNA Extraction Kit (SIGMA ${ }^{\circ}$, Saint Louis, MO) methodology. DNA quality was verified using electrophoresis with $1 \%$ agarose gels, while quantity was verified using a Qubit $^{\circ} 2.0$ fluorometer (Invitrogen, Carlsbad, CA).

DNA samples (30 $\mu$ l of $10 \mathrm{ng} \mathrm{l}^{-1}$ DNA) were transferred to Plate-forme D'analyses Génomiques at Université Laval (Laval, Quebec, Canada) for genotyping-bysequencing (GBS), using the Fast-GBS pipeline with the Gmax_275_v2 reference genome [88]. The Fast-GBS pipeline identified 24,738 high-quality single-nucleotide polymorphisms (SNPs). Heterozygous SNPs were considered missing data. SNPs with $>20 \%$ missing data or a minimum minor allele frequency less than 0.3 were discarded prior to imputation with Beagle [89].

\section{Linkage map construction and QTL mapping}

JoinMap 5.0 software was used to construct genetic linkage maps for each population [90]. SNP markers with significant levels of segregation distortion that differed from the expected 1:1 ratio based on a chi-square test $(\alpha=0.01)$ were removed from further analysis. Markers that segregated identically within the population were reduced to a single marker for linkage map construction. Markers were grouped into linkage groups within each chromosome using a minimum likelihood of odds $(\mathrm{LOD}) \geq 3$, and Kosambi's mapping function was used to calculate genetic distances. Thereafter, the genetic position of these markers was anchored on physical position.

Composite interval mapping (CIM) was performed for the traits of interest using the multiple QTL mapping (MQM) algorithm in MapQTL 6 [91]. The empirical LOD threshold values were calculated through a permutation test with 1000 iterations and a Type I error rate of 0.05 . The automatic cofactor selection function was used to identify significant cofactors for MQM. Graphic representations of significant QTL were created using MapChart 2.32 [92].

Putative QTL regions associated with seed protein concentration were also screened for significant QTL associated with seed weight, seed yield and seed sucrose concentration. SoyBase was used to compare the putative QTL to published genomic regions related to seed protein concentration [38]. Putative QTL were also confirmed in the alternate population using single marker analysis (SMA) in SAS 9.4 (SAS Institute Inc., Cary, NC). PROC GLM was used to identify significant single marker effects $(\alpha<0.0001)$ with LSMEAN estimates as the dependent variable and SNP marker as the independent variable. The SNP positions from genotype-bysequencing were used to denote marker names in MQM and SMA.

\section{Candidate gene search}

The flanking markers of each QTL were chosen based on the LOD values surrounding each peak marker. To ensure that the actual QTL was located within the range selected, the first marker below the LOD threshold on each side of the QTL peak was selected as the flanking marker. For each of the protein-related QTL, the regions between the flanking markers were used to identify candidate genes according to their function. A total of 491 genes were extracted from the flanking regions using the SoyBase Soybean Genetic Map. The functional annotation of each gene was identified from TAIR (www.arabidopsis.org/), GO (http://geneontology.org/), PFAM (http://pfam.xfam.org/), and PANTHER (http://www. pantherdb.org/) through SoyBase (https://soybase.org/). This functional knowledge used to reduce number of genes and identify putative candidate genes.

The Electronic Fluorescent Pictograph (eFP) browser for soybean (www.bar.utoronto.ca) was used to generate additional information about the candidate genes, such as tissue- and developmental-stage dependent expression (based on transcriptomic data from Severine et al. [54]). Pfam, a comprehensive collection of protein domains and families, and NCBI were used to obtain additional information about candidate genes.

\section{Supplementary information}

Supplementary information accompanies this paper at https://doi.org/10. 1186/s12870-020-02681-0.

\footnotetext{
Additional file 1 : Supplementary Table S1. Mean, standard error $(a=0.05)$, range, and parental means for soybean seed protein concentration (\%, dry weight basis) in two RIL populations, 'AC X790P' $x$ 'S18-R6' and 'AC X790P' x 'S23-T5', in five environments: Chatham 2015, Chatham 2016, Merlin 2015, Merlin 2016 and Palmyra 2016.

Supplementary Table S2. Mean, standard error $(a=0.05)$, range, and parental means for soybean seed yield (tonnes ha ${ }^{-1}$ ) in two RIL populations, 'AC X790P' x 'S18-R6' and 'AC X790P' x 'S23-T5', in five environments: Chatham 2015, Chatham 2016, Merlin 2015, Merlin 2016 and Palmyra 2016. Supplementary Table S3. Mean, standard error $(a=$ 0.05), range, and parental means for soybean seed weight (100 seed weight in grams) in two RIL populations, 'AC X790P' X 'S18-R6' and 'AC X790P' X 'S23-T5', in five environments: Chatham 2015, Chatham 2016, Merlin 2015, Merlin 2016 and Palmyra 2016. Supplementary Table S4. Mean, standard error $(a=0.05)$, range, and parental means for soybean seed sucrose concentration (\%, dry basis) in two RIL populations, 'AC X790P' X 'S18-R6' and 'AC X790P' X 'S23-T5', in five environments: Chatham 2015, Chatham 2016, Merlin 2015, Merlin 2016 and Palmyra
} 
2016. Supplementary Table S5. Broad-sense heritability of protein concentration, sucrose concentration, seed weight and seed yield in two RIL populations evaluated in five environments (CHA15, CHA16, MER15, MER16 and PAL16). Supplementary Table S6. Pearson correlation coefficients for seed protein and sucrose concentrations, 100-seed weight and seed yield in five environments (Chatham 2015, Chatham 2016, Merlin 2015, Merlin 2016, and Palmyra 2016) as well as the combined environment for the recombinant inbred line populations. Supplementary Table S7. Summary of major putative QTL $\left(R^{2}>10.0 \%\right)$ associated with soybean seed protein concentration, sucrose concentration and seed weight with potential use in marker-assisted selection, candidate genes, and co-localized QTL in the previous studies. Supplementary Table S8. Major putative QTL $\left(R^{2}>10.0 \%\right)$ associated with soybean seed sucrose concentration, yield and seed weight with potential use in markerassisted selection, identified by multiple QTL mapping (MQM) in RIL populations examined under combined Ontario environments in 2015 and 2016. Supplementary Table S9. Whole-seed (dry basis) calibration values for oil, protein, Moisture and fatty acid components, as provided by Perten Instruments. The coefficient of determination for crossvalidation $\left(R^{2} C V\right)$ explains the proportion of variance that can be predicted between reference chemistry and predicted values. The minimum and maximum values are the limits of the prediction range. The SECV is the standard error of cross validation, where samples are removed from the validation set and predicted, and the total error for the dataset is calculated. Factors shows the number of factors included in the calibration equation for a given trait. Samples shows the total number of samples used in the calibration. Calibration file dates for each trait are listed.

\section{Abbreviations}

QTL: Quantitative trait loci; MAS: Marker-assisted selection; RIL: Recombinant inbred line; DAF: Day after flowering; POPn_1: First population; POPn_2: Second population; MG: Maturity group; CHA15: Chatham 2015; MER15: Merlin 2015; CHA16: Chatham 2016; MER16: Merlin 2016; PAL16: Palmyra 2016; NNA: Nearest neighbour analysis; NIR: Near-infrared reflectance; ANOVA: Analysis of variance; SNPs: Single-nucleotide polymorphisms; CIM: Composite interval mapping; MQM: Multiple QTL mapping; LOD: Likelihood of odds; SMA: Single marker analysis; eFP: electronic Fluorescent Pictograph

\section{Acknowledgements}

The authors would like to thank Bryan Stirling, Chris Grainger, John Kobler, and the entire soybean crew at the University of Guelph, Ridgetown Campus for their technical support.

\section{Authors' contributions}

RMW and ME conceived and designed the experiments; ME supervised the study; RMW conducted the experiments, collected phenotypic data, and performed statistical analyses; ST performed candidate genes identification; RMW and ST drafted the manuscript; LL and ME supervised statistical analyses and revised the manuscript. All authors have read and approved the final manuscript

\section{Funding}

This project was funded in part by SeCan and the Ontario Agri-Food Innovation Alliance (previously the OMAFRA-U of G Partnership), which is a collaboration between the Ontario Ministry of Agriculture, Food \& Rural Affairs (OMAFRA) and the University of Guelph ( $G$ of $G$ ). The funding bodies did not play any role in the design of the study and collection, analysis, and interpretation of data and in writing the manuscript.

\section{Availability of data and materials}

The phenotypic and genotypic data that support the findings of this study are openly available in figshare at https://doi.org/10.6084/m9.figshare. 13008467.

\section{Ethics approval and consent to participate}

Not applicable.

\section{Consent for publication}

Not applicable.

\section{Competing interests}

The authors declare that they have no competing interests.

Received: 19 June 2020 Accepted: 30 September 2020 Published online: 23 October 2020

\section{References}

1. Wang $\mathrm{HL}$, Hesseltine CW. Coagulation conditions in tofu processing. Process Biochem. 1983;17:7-12.

2. Shen CF, DeMan L, Buzzell RI, DeMan JM. Yield and quality of tofu as affected by soybean and soymilk characteristics: glucono- $\delta$-lactone coagulant. J Food Sci. 1991;56:109-12.

3. Schaefer MJ, Love J. Relationships between soybean components and tofu texture. J Food Qual. 1992;15:53-66.

4. Cai T, Chang KC. Processing effect on soybean storage proteins and their relationship with tofu quality. J Agric Food Chem. 1999;47:720-7.

5. Poysa V, Woodrow L. Stability of soybean seed composition and its effect on soymilk and tofu yield and quality. Food Res Inst. 2002;35:337-45.

6. Kim Y, Wicker L. Soybean cultivars impact quality and function of soymilk and tofu. J Sci Food Agric. 2005;85:2514-8.

7. Stanojevic SP, Barac MB, Pesic MB, Vucelic-Radovic BV. Assessment of soy genotype and processing method on quality of soybean tofu. J Agric Food Chem. 2011;59:7368-76.

8. Carver BF, Burton JW, Carter TE, Wilson RF. Response to environmental variation of soybean lines selected for altered unsaturated fatty acid composition. Crop Sci. 1986:26:1176-81.

9. Vollmann J, Fritz CN, Wagentristl H, Ruckenbauer P. Environmental and genetic variation of soybean seed protein content under central European growing conditions. J Sci. 2000;1306:1300-6.

10. Sudaric A, Simic D, Vrataric M. Characterization of genotype by environment interactions in soybean breeding programmes of Southeast Europe. Plant Breed. 2006;125:191-4

11. Akond M, Liu S, Boney M, Kantartzi SK, Meksem K, Bellaloui N, et al. Identification of quantitative trait loci (QTL) underlying protein, oil, and five major fatty acids contents in soybean. Am J Plant Sci. 2014;5:158-67.

12. Chaudhary J, Patil GB, Sonah H, Deshmukh RK, Vuong TD, Valliyodan B, et al. Expanding omics resources for improvement of soybean seed composition traits. Front Plant Sci. 2015;6:1021.

13. Ma Y, Kan G, Zhang X, Wang Y, Zhang W, Du H, et al. Quantitative trait loci (QTL) mapping for glycinin and beta-conglycinin contents in soybean (Glycine max L. Merr). J Agric Food Chem. 2016;64:3473-83.

14. Shannon G, Wilcox JR, Probst AH. Estimated gains from selection for protein and yield in the F4 generation of six soybean populations. Crop Sci. 1972; 12:824-6.

15. Burton JW. Breeding soybeans for improved protein quantity and quality. In: Shibles R, editor. 3rd soybean research conference, Ames, IA, 12-17 Aug 1984. Boulder: Westview Press; 1985. p. 361-7.

16. Burton JW. Quantitative genetics: results relevant to soybean breeding. In: Wilcox JR, editor. Soybeans: improvement, production, and uses. Madison: American Society of Agronomy; 1987. p. 211-47.

17. Wilcox JR, Cavins JF. Backcrossing high seed protein to a soybean cultivar. Crop Sci. 1995:35:1036-41.

18. Helms TC, Orf JH. Protein, oil, and yield of soybean lines selected for increased protein. Crop Sci. 1998;38:707-11.

19. Chung J, Babka H, Graef G, Staswick P, Lee D, Cregan P, et al. The seed protein, oil, and yield QTL on soybean linkage group I. Crop Sci. 2003;43: 1053-67.

20. Cui Z, James AT, Mizazaki S, Wilson RF, Carter TE. Breeding specialty soybeans for traditional and new soyfoods. In: Liu K, editor. Soybeans as functional foods and ingredients. Champaign: AOCS Press; 2004. p. 264-322.

21. Yin X, Vyn TJ. Relationships of isoflavone, oil, and protein in seed with yield of soybean. Agron J. 2005;97:1314-21

22. Bandillo N, Jarquin D, Song Q, Nelson R, Cregan P, Specht J, et al. A population structure and genome-wide association analysis on the USDA soybean germplasm collection. Plant Genome. 2015:8:1-13.

23. Kim M, Schultz S, Nelson RL, Diers BW. Identification and fine mapping of a soybean seed protein QTL from PI 407788A on chromosome 15. Crop Sci. 2016:56:219.

24. Zeng J, Chen P, Shi A, Wang D, Zhang B, Orazaly M, et al. Identification of quantitative trait loci for sucrose content in soybean seed. Crop Sci. 2015;54 554-64. 
25. Hymowitz T, Collins Fl, Panczner J, Walker WM. Relationship between the content of oil, protein, and sugar in soybean seed. Agron J. 1972;64:613-6.

26. Brummer EC, Graef GL, Orf J, Wilcox JR, Shoemaker RC. Mapping QTL for seed protein and oil content in eight soybean populations. Crop Sci. 1997; 37(2):370-8

27. Fasoula VA, Harris DK, Boerma HR. Validation and designation of quantitative trait loci for seed protein, seed oil, and seed weight from two soybean populations. Crop Sci. 2004;44(4):1218-25.

28. Lee SH, Bailey MA, Mian MAR, Carter TE, Shipe ER, Ashley DA, et al. RFLP loci associated with soybean seed protein and oil content across populations and locations. Theor Appl Genet. 1996;93(5-6):649-57.

29. Warrington CV, Abdel-Haleem H, Hyten DL, Cregan PB, Orf JH, Killam AS, et al. QTL for seed protein and amino acids in the Benning $\times$ Danbaekkong soybean population. Theor Appl Genet. 2015;128(5):839-50.

30. Mao T, Jiang Z, Han Y, Teng W, Zhao X, Li W. Identification of quantitative trait loci underlying seed protein and oil contents of soybean across multigenetic backgrounds and environments. Plant Breed. 2013;132(6):630-41.

31. Qi Z, Hou M, Han X, Liu C, Jiang H, Xin D, et al. Identification of quantitative trait loci (QTL s) for seed protein concentration in soybean and analysis for additive effects and epistatic effects of QTL s under multiple environments. Plant Breed. 2014:133(4):499-507.

32. Stombaugh SK, Orf JH, Jung HG, Chase K, Lark KG, Somers DA. Quantitative trait loci associated with cell wall polysaccharides in soybean seed. Crop Sci. 2004:44(6):2101-6

33. Wang $X$, Jiang $G L$, Green $M$, Scott RA, Song $Q$, Hyten DL, Cregan PB. Identification and validation of quantitative trait loci for seed yield, oil and protein contents in two recombinant inbred line populations of soybean. Mol Gen Genomics. 2014:289(5):935-49.

34. Rossi ME, Orf JH, Liu LJ, Dong Z, Rajcan I. Genetic basis of soybean adaptation to North American vs. Asian mega-environments in two independent populations from Canadianx Chinese crosses. Theor Appl Genet. 2013;126(7):1809-23.

35. Palomeque L, Li-Jun L, Li W, Hedges B, Cober ER, Rajcan I. QTL in megaenvironments: II. Agronomic trait QTL co-localized with seed yield QTL detected in a population derived from a cross of high-yielding adapted $\mathrm{x}$ high-yielding exotic soybean lines. Theor Appl Genet. 2009;119:429-36.

36. Liang HZ, Yu YL, Wang SF, Yun LIAN, Wang TF, Wei YL, et al. QTL mapping of isoflavone, oil and protein contents in soybean (Glycine max L. Merr.). Agric Sci China. 2010;9(8):1108-16.

37. SoyBase. SoyBase, the USDA-ARS soybean genetics and genomics database. 2019. https://soybase.org/. Accessed 5 Apr 2019.

38. Patil G, Mian R, Vuong T, Pantalone V, Song Q, Chen P, et al. Molecular mapping and genomics of soybean seed protein: a review and perspective for the future. Theor Appl Genet. 2017;130:1975-91.

39. Qi Z, Zhang Z, Wang Z, Yu J, Qin H, Mao X, et al. Meta-analysis and transcriptome profiling reveal hub genes for soybean seed storage composition during seed development. Plant Cell Environ. 2018:41:2109-27.

40. Panthee DR, Pantalone V, West DR, Saxton AM, Sams CE. Quantitative trait loci for seed protein and oil concentration, and seed size in soybean. Crop Sci. 2005;45:2015-22

41. Bernardo R. Breeding for quantitative traits in plants. 2nd ed. Woodbury: Stemma Press; 2010.

42. Qi Z, Wu Q, Han X, Sun Y, Du X, Liu C, et al. Soybean oil content QTL mapping and integrating with mate-analysis method for mining genes. Euphytica. 2011;179:499-514

43. Kadam S, Vuong TD, Qiu D, Meinhardt CG, Song L, Deshmukh R, et al. Genomic-assisted phylogenetic analyses and marker development for next generation soybean cyst nematode resistance breeding. Plant Sci. 2015;242: 342-50.

44. Wang X, Jiang G, Song Q, Cregan P, Scott R, Zhang J, et al. Quantitative trait locus analysis of seed Sulphur-containing amino acids in two recombinant inbred line populations of soybean. Euphytica. 2015;201:293-305.

45. Jofuku KD, Goldberg RB. Kunitz trypsin inhibitor genes are differentially expressed during the soybean life cycle and in transformed tobacco plants. Plant Cell. 1989;1:1079-93.

46. Walling L, Drews GN, Goldberg RB. Transcriptional and post-transcriptional regulation of soybean seed protein mRNA levels. Proc Natl Acad Sci U S A 1986;83:2123-7.

47. Yeh KW, Chen JC, Lin Ml, Chen YM, Lin CY. Functional activity of sporamin from sweet potato (Ipomoea batatas lam.): a tuber storage protein with trypsin inhibitory activity. Plant Mol Biol. 1997;33:565-70.
48. Lotan T, Ohto MA, Yee KM, West MA, Lo R, Kwong RW, et al. Arabidopsis LEAFY COTYLEDON1 is sufficient to induce embryo development in vegetative cells. Cell. 1998;1:1195-205.

49. Soderman EM, Brocard IM, Lynch TJ, Finkelstein RR. Regulation and function of the Arabidopsis ABA-insensitive4 gene in seed and abscisic acid response signaling networks. Plant Physiol. 2000;124:1752-65.

50. Hyten DL, Pantalone VR, Sams CE, Saxton AM, Landau-Ellis D, Stefaniak TR, et al. Seed quality QTL in a prominent soybean population. Theor Appl Genet. 2004;109:552-61.

51. Baianu I, You T, Costescu D, Lozano P, Prisecaru V, Nelson R. Determination of soybean oil, protein and amino acid residues in soybean seeds by high resolution nuclear magnetic resonance (NMRS) and near infrared (NIRS). Nat Precedings. 2012;7:1-1.

52. Patil G, Vuong TD, Kale S, Valliyodan B, Deshmukh R, Zhu C, et al. Dissecting genomic hotspots underlying seed protein, oil, and sucrose content in an interspecific mapping population of soybean using high-density linkage mapping. Plant Biotechnol. J. 2018;16:1939-53.

53. Whaley R, Eskandari M. Genotypic main effect and genotype-byenvironment interaction effect on seed protein concentration and yield in food-grade soybeans (Glycine max (L.) Merrill). Euphytica. 2019;215:33.

54. Severin AJ, Woody JL, Bolon YT, Joseph B, Diers BW, Farmer AD, et al. RNAseq atlas of Glycine max: a guide to the soybean transcriptome. BMC Plant Biol. 2010;10:160.

55. Dunwell JM. Cupins: a new superfamily of functionally diverse proteins that include germins and plant storage proteins. Biotechnol Genet Eng. 1998;15: $1-32$.

56. Nichols D, Glover K, Carlson S, Specht J, Diers B. Fine mapping of a seed protein QTL on soybean linkage group I and its correlated effects on agronomic traits. Crop Sci. 2006;46:834.

57. Jaureguy LM, Chen P, Scaboo AM. Heritability and correlations among foodgrade traits in soybean. Plant Breed. 2011;130:647-52.

58. Sonah H, O'Donoughue L, Cober E, Rajcan I, Belzile F. Identification of loci governing eight agronomic traits using a GBS? WAS approach Valid by QTL Mapp soya bean. 2015:12:211-21.

59. Poysa V, Buzzell RI. AC X790P soybean. Can J Plant Sci. 2001;81:447-8.

60. Eskandari M, Cober ER, Rajcan I. Genetic control of soybean seed oil: I. QTL and genes associated with seed soil concentration in RIL populations derived from crossing moderately high-oil parents. Theor Appl Genet. 2013; 126:483-95

61. Maughan PJ, Maroof MS, Buss GR. Identification of quantitative trait loci controlling sucrose concentration in soybean (Glycine max). Mol Breed. 2000;6:105-11.

62. Kelly JD, Afanador L, Haley SD. Pyramiding genes for resistance to bean common mosaic virus. Euphytica. 1995:82:207-12.

63. Miklas PN, Delorme R, Stone V, Daly MJ, Stavely JR, Steadman JR, et al. Bacterial, fungal, and viral disease resistance loci mapped in a recombinant inbred common bean population ('Dorado'/XAN 176). J Am Soc Hortic Sci. 2000;176:476-81.

64. Singh S, Sidhu JS, Huang N, Vikal Y, Li Z, Brar DS, et al. Pyramiding three bacterial blight resistance genes (xa5, xa13 and Xa21) using marker-assisted selection into indica rice cultivar PR106. Theor Appl Genet. 2001:13:1011-5.

65. Maroof S, Jeong SC, Gunduz I, Tucker DM, Buss GR, Tolin SA. Pyramiding of soybean mosaic virus resistance genes by marker-assisted selection. Crop Sci. 2008;48:517-26.

66. Jiang Z, Han Y, Teng W, Zhang Z, Sun D, Li Y, et al. Identification of QTL underlying the filling rate of protein at different developmental stages of soybean seed. Euphytica. 2010;175:227-36.

67. Asins MJ. Present and future quantitative trait locus analysis in plant breeding. Plant Breed. 2002:121:281-91.

68. Winter S, Shelp BJ, Anderson TR, Welacky TW, Rajcan I. QTL associated with horizontal resistance to soybean cyst nematode in Glycine soja PI464925B. Theor Appl Genet. 2007;114:461-72.

69. Hyne V, Kearsey MJ. QTL analysis: further uses of marker regression. Theor Appl Genet. 1995;91:471-6.

70. Kearsey M, Farquhar A. QTL analysis in plants: where are we now? Heredity. 1998:80:137-42.

71. Beavis WD. QTL analyses: Power, precision and accuracy. In: Paterson AH, editor. Molecular Dissection of Complex Traits. Boca Raton, FL: CRC Press; 1998. p. 145-62.5

72. Xu S. Theoretical basis of the Beavis effect Genetics. 2003:165:2226-59. 
73. Hagely KB, Jo H, Kim JH, Hudson KA, Bilyeu K. Molecular-assisted breeding for improved carbohydrate profiles in soybean seed. Theor Appl Genet. 2020;133:1189-200.

74. Hagely KB, Palmquist D, Bilyeu KD. Classification of distinct seed carbohydrate profiles in soybean. J Agric Food Chem. 2013;61:1105-11.

75. Schillinger, John A., Emily C. Dierking, and Kristin D. Bilyeu. Soybeans having high germination rates and ultra-low raffinose and stachyose content. U.S. Patent 8, 471,107, issued June 25, 2013.

76. Morales AM, O'Rourke JA, Scheider K, Bancroft T, Borem A, Nelson R, et al. Transcriptome analyses and virus induced gene silencing identify genes in the RRpp4-mediated Asian soybean rust resistance pathway. Funct Plant Biol. 2013;4:1029-47.

77. Yaklich RW, Helm RM, Cockrell G, Herman EM. Analysis of the distribution of the major soybean seed allergens in a core collection of Glycine max accessions. Crop Sci. 1999:39:1444-7.

78. Zhang T, Wu T, Wang L, Jiang B, Zhen C, Yuan S, et al. A combined linkage and GWAS analysis identifies QTLs linked to soybean seed protein and oil content. Int J Mol Sci. 2019;20:5915.

79. Li X, Shao Z, Tian R, Zhang H, Du H, Kong Y, et al. Mining QTLs and candidate genes for seed protein and oil contents across multiple environments and backgrounds in soybean. Mol Breed. 2019:39:139.

80. Rolletschek H, Hosein F, Miranda M, Heim U, Gotz KP, Schlereth A, et al. Ectopic expression of an amino acid transporter (VfAAP1) in seeds of Vicia narbonensis and pea increases storage proteins. Plant Physiol. 2005;1:1236-49.

81. Canadian Food Inspection Agency (CFIA). Crop Reports: S18-R6. 2011. http:// www.inspection.gc.ca/english/plaveg/pbrpov/cropreport/soy/app00006462e. shtml. Accessed 13 Oct 2016.

82. Canadian Food Inspection Agency (CFIA). Crop Reports: S23-T5. 2011. http:// www.inspection.gc.ca/english/plaveg/pbrpov/cropreport/soy/app00007153e. shtml. Accessed 13 Oct 2016.

83. Ontario Ministry of Agriculture Food and Rural Affairs (OMAFRA). Provincial field crop production and prices. 2016. http://www.omafra.gov.on.ca. Accessed 21 Dec 2017.

84. Kovalenko IV, Rippke GR, Hurburgh CR. Mea- surement of soybean fatty acids by near-infrared spectroscopy: Linear and nonlinear calibration methods. J Am Oil Chem. 2006;(Soc. 83):421-7. https://doi.org/10.1007/ s11746-006-1221-z.

85. Hurburgh CR. Measurement of fatty acids in whole soy- beans with near infrared spectroscopy. Lipid Technol. 2007;19:88-90. https://doi.org/10.1002/ lite. 200600029

86. Bellaloui N, Mengistu A, Walker ER, Young LD. Soybean seed composition as affected by seeding rates and row spacing. Crop Sci. 2014;54:1782-18795. https://doi.org/10.2135/crop-sci2013.07.0463.

87. Butler $\mathrm{JA}$, De Bruin $\mathrm{J} \mathrm{L}$, Pedersen P. Plant density effect on reduced linolenic acid soybean cultivars. Agron J. 2010;102:348. https://doi.org/10.2134/ agronj2009.0167.

88. Torkamaneh D, Laroche J, Bastien M, Abed A, Belzile F. Fast-GBS: a new pipeline for the efficient and highly accurate calling of SNPs from genotype-by-sequencing data. BMC Bioinformatics. 2017;18:5.

89. Browning BL, Browning SR. Genotype imputation with millions of reference samples. Am J Hum Genet. 2016;98:116-26.

90. van Ooijen JW. JoinMap 4.0: Software for the calculation of genetic linkage maps in experimental populations; 2006

91. van Ooijen JW. MapQTL ${ }^{\bullet} 6$, Software for the mapping of quantitative trait loci in experimental populations of diploid species; 2009.

92. Voorrips RE. MapChart: software for the graphical presentation of linkage maps and QTLs. J Hered. 2002:77-8.

\section{Publisher's Note}

Springer Nature remains neutral with regard to jurisdictional claims in published maps and institutional affiliations.

Ready to submit your research? Choose BMC and benefit from:

- fast, convenient online submission

- thorough peer review by experienced researchers in your field

- rapid publication on acceptance

- support for research data, including large and complex data types

- gold Open Access which fosters wider collaboration and increased citations

- maximum visibility for your research: over $100 \mathrm{M}$ website views per year

At BMC, research is always in progress.

Learn more biomedcentral.com/submissions 